\title{
"Vapaus, autonomia ja hyvinvointi ovat elinikäisen oppimisen ydintä”
}

Vuoden 2016 tiedeartikkelin kirjoittaja Antti Saari

kyseenalaistaa elinikäisen oppimisen siinä muodossa

kuin se on omaksuttu vallankäytön välineeksi.

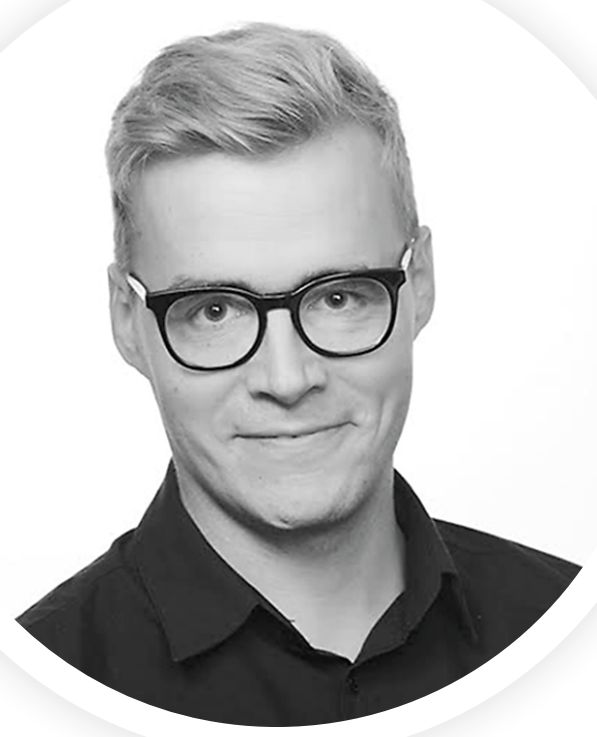

Tutkimuksessaan Antti Saari on perehtynyt kasvatushistoriaan, kasvatusfilosofiaan ja opetussuunnitelmatutkimukseen. 
PALKITUSSA ARTIKKELISSAAN "Elinikäinen oppiminen ja yksilöivä valta" Antti Saari tarttuu kriittisellä otteella jatkuvaan itsensä kehittämisen ideaaliin. Hän selvittää, miten valta on tunkeutunut 'elinikäisen oppimisen' käsitteeseen.

Aikuiskasvatuksen toimituskunta luonnehtii tekstiä teoreettisesti ansiokkaaksi ja oivaltavaksi.

"Artikkeli on tärkeä ja tuore tutkimuksellinen puheenvuoro ja avaus elinikäisen oppimisen kriittiseen hallinnanteoreettiseen keskusteluun," raati perustelee.

\section{OPPIMINEN ON KAIKKIALLISTA}

Tampereen yliopistossa työskentelevän Antti Saaren mukaan elinikäinen oppiminen ilmaisee sitä, että ihmisen on syytä olla alati valmiina muuttumaan työympäristönsä ja vaihtelevien elämäntilanteidensa mukana.

Oppimista ei voi paikantaa mihinkään tiettyyn instituutioon tai elämänvaiheeseen.

”Elinikäisessä oppimisessa ei kuitenkaan ole kyse pelkästään ihmisen alistamisesta koulutuksen ja työelämän arvaamattomille markkinoille. Sen sijaan elinikäisessä oppimisessa on hyvin vahvasti panoksena ihmisen vapaus, autonomia ja hyvinvointi. Juuri siksi siitä täytyy käydä kriittistä keskustelua”, Saari sanoo.

\section{TIEDE LAVENTAA NÄKÖKULMAA}

Aikuiskasvatustieteelle on luontaista kriittinen, instituutioiden ja tieteiden väliset rajat ylittävä keskustelu. Se sopii Saarelle.

"En pyri tarjoamaan helppoja vastauksia vaan päinvastoin pitämään ihmisen kasvua ja sivistystä koskevia kysymyksiä aidosti avoimina, monisyisinä ja huomionarvoisina”, hän sanoo.

Tutkijan mielestä aikuiskasvatustiedettä tarvitaan avaamaan laajoja, sivistystä koskevia ikkunoita tutkimuksesta yhteiskuntaan.

"Samalla kun tieteelliseen asiantuntijuuteen perustuvasta keskustelusta on tulossa 'totuudenjälkeisenä aikana' entistä hankalampaa, sitä kipeämmin tarvitaan aikuiskasvatustieteilijöitä nostamaan esille sivistyksellisen tasa-arvon, oikeudenmukaisuuden ja hyvän elämän kysymyksiä.” 